\title{
Väljundipõhine õpe - kas õppimisse panustava ja kaasatud üliõpilase kujundaja?
}

\author{
Kaija Kumpas-Lenk ${ }^{\text {a1 }}$, Eve Eisenschmidt ${ }^{\mathrm{a}}$, Kirsti Rumma ${ }^{\mathrm{a}}$ \\ a Tallinna Ülikooli haridusteaduste instituut
}

\begin{abstract}
Annotatsioon
Artikli aluseks oleva kvantitatiivse uuringu eesmärk on välja selgitada, kuidas üliõpilased ja õppejõud hindavad väljundipõhise õppe rakendumist õpiväljundite omandamist toetavate komponentide toel. Kuue Eesti kõrgkooli üliõpilaste $(n=1329)$ ja õppejõudude $(n=94)$ hinnangutest selgub, et õpiväljundite arusaadavus, õpikeskkond, õppematerjalid, sooritatud tööd, hindamisülesanded, tagasiside, tööde maht, õpetamine, õppijate motivatsioon ja rahulolu toetavad õpiväljundite saavutamist. Samas ilmneb uuringust, et üliõpilased ei panusta ise õppetöösse piisavalt ning ei ole kaasatud õppeprotsessi. Õppetöösse panustamist iseloomustavad peamiselt õppimisse kaasatuse, õppijate motivatsiooni ja tööde mahu tulemused. Õppimisse kaasatust ennustavad enamasti óppimisse panustamise, õppijate motivatsiooni ja rahulolu tulemused. Õppejõudude ja üliõpilaste hinnangud enamiku õpiväljundite omandamist toetavate komponentide kohta oluliselt ei erinenud, v.a hindamisülesannete, õppija motivatsiooni ja kursusega rahulolu puhul. Tulemused näitavad, et senisest enam on vaja toetada õppijaid aktiivse rolli ning vastutuse võtmisel.
\end{abstract}

Võtmesõnad: väljundipõhine õpe, õppeprotsessi komponendid, üliõpilaste kaasatus, õppimisse panustamine, üliõpilaste ja õppejõudude hinnangud

\section{Sissejuhatus}

Väljundipõhine õpe on Euroopa kõrgharidusmaastikul olnud aktuaalne 1999. aastal välja kuulutatud Bologna deklaratsioonist alates (Udam, 2008). Adami (2008) uuringu kohaselt on õpiväljunditena kirjeldatud oskused, teadmised ja hoiakud ülitähtsad, toetamaks õppijast lähtuva õppimise ja õpetamise rakendumist. Traditsiooniliselt on õppekavade koostamisel olnud rõhuasetus sisendil, väljundipõhine õpe seab aga keskmesse õppija ning õpiväljundi saavutamise (Biggs \& Tang, 2009; Udam, 2008), mis eeldab nii kõrgkoolidelt, õppe-

Haridusteaduste instituut, Tallinna Ülikool, Uus-Sadama 5, 10120 Tallinn; kkumpas@gmail.com 
jõududelt kui ka üliõpilastelt senistes õpetamis- ja õppimisviisides fundamentaalseid muudatusi. See on liikumine õppijakeskse õppe suunas, kus õppija ise on aktiivne ja kaasatud ning vastutab oma teadmiste loomise ning õppe kavandamise eest (Barr \& Tagg, 1995; Biggs \& Tang, 2009; Huba \& Freed, 2000). Kavandatud ópiväljunditest ja nende hindamisviisidest teadlik olek annab õppijale suuremad võimalused osaleda õppeprotsessis ning leida enda jaoks sobivaid viise liikumisel eesmärgi poole (Rutiku, Valk, Pilli, \& Vanari, 2009).

Kõrgharidusstandardi (2008) kohaselt on õpiväljundid (õpitulemused, ingl learning outcomes) „õppimise tulemusel omandatavad teadmised, oskused ja hoiakud, mis on kirjeldatud õppekava, mooduli või õppeaine läbimiseks vajalikul miinimumtasemel“. Väljundipõhine õpe (ingl outcome based education) on „õppijakesksele lähenemisele tuginev õppekava eesmärgistamine ja õppetegevuse korraldamine, milles põhitähelepanu on hinnatavatel õpiväljunditel“ (Pilli, 2009, lk 7).

Kuigi õpiväljundite eesmärk on õppija individuaalse arengu maksimaalne toetamine, näitavad uuringud, et väljundipõhine õpe ei ole ootuspärasel määral rakendunud (Pilli \& Vanari, 2013; Tammets \& Pata, 2013; Udam, Seema, \& Mattisen, 2015). Need õilsad eesmärgid ei saagi realiseeruda, kui nende põhirakendajad - õppejõud - ei ole mõistnud muudatuste põhjuseid ega oska muudatusi rakendada, mis omakorda võib süvendada õppejõudude ja üliõpilaste kriitikat väljundipõhise õppe pihta (Tina, 2008). Seetõttu on ilmselt ka Bologna protsessi nimetatud pealesurutud reformiks ja formaalsuseks, kus õpiväljundeid nähakse bürokraatliku kohustusena, mis täidab auditeerimise ja kvaliteedihindamise eesmärke ega vasta õppija tegelikele vajadustele (Hussey \& Smith, 2008).

Enamik senistest väljundipõhise õppe uuringutest keskendub institutsioonide ja reformide tasandi ülesannetele, vähem õppejõudude ja üliõpilaste kogemustele ning muutustele õppija arengus (Hadjianastasis, 2016; Lea, Stephenson, \& Troy, 2003). Siinkohal on ühelt poolt parajaks proovikiviks õpetamisprotsessi elementide (õpiväljundite ja -ülesannete, hindamise, tagasiside) kavandamine ning see, kuidas õppijad neid tajuvad. Teisalt aga valmistavad raskusi õppija motivatsioon, kaasatus ja valmisolek osaleda õppijast lähtuvas õppeprotsessis. Kuna väljundipõhise õppe üks peamisi eesmärke on toetada õppijakeskse õppe rakendamist, siis uurimegi, kas väljundipõhisele õppele üleminek täidab oma eesmärki.

\section{Väljundipõhine õpe Eesti kõrghariduses}

Eesti kõrgharidusse jõudsid õpiväljundid 2007. aastal kõrgharidusstandardi jõustamisega, millega kehtestati nõuded eri õppetasemetelt oodatavatele õpitulemustele (Valk, 2008). Kuigi õpiväljunditest lähtuvat kõrgharidusõpet on 
Eestis rakendatud alates 2009. aastast (Kõrgharidusstandard, 2008), on korraldatud siiski üsna vähe uuringuid, mis kajastaksid väljundipõhise õppe tegelikku rakendamist. Pilli ja Vanari (2013) hinnangul ei ole üleminek väljundipõhisele õppele olnud kerge, kuid on näha positiivseid trende - õpiväljundite, hindamise ja õpiülesannete omavaheline kooskõla ning seostatus on aastatega paranenud. Seevastu Tammets ja Pata (2013) on leidnud, et õppejõud lähtuvad õpiväljundite sõnastamisel õppeülesannetest ja nende hindamisest, mitte kõrgharidusstandardis ette antud raamistikust. Kuigi nii kõrgharidusstandardis kui ka paljudes haridussüsteemi tulevikutrende käsitlevates kirjutistes rõhutatakse üldpädevuste, nagu kriitilise mõtlemise, eetilise probleemikäsituse, loovuse ja suhtlemisoskuste olulisust, ei ole nende süsteemne arendamine õpiväljundites piisavalt kajastatud (Kumpas-Lenk \& Eisenschmidt, esitatud). Udami jt (2015) uuringust aga selgus, et óppijate individuaalse ja sotsiaalse arengu toetamiseks on õpetamis- ja õppimisparadigma vaja muuta õppijakeskseks. Sama eesmärk on seatud „Eesti elukestva õppe strateegias 2020“ (Eesti elukestva õppe strateegia, 2014), kus eelolevale lisaks rõhutatakse õpioskuste, loovuse ja ettevõtlikkuse toetamise olulisust.

Üliõpilaste uuringute tulemused viimastest aastatest annavad aimu, kuidas väljundipõhises õppes õpitakse ning millised on üliõpilaste ootused, hinnangud ja valmisolek uuel viisil óppimiseks. Varasematest uuringutest on selgunud, et üliõpilased on rahul kõrgharidusõppega (Kumpas-Lenk, esitatud). Nende rollikujutuses domineerib töökuse, kuulekuse ja korrektsuse mõõde (Vadi, Reino, \& Aidla, 2014). Sellest hoolimata on väljundipõhist õpet iseloomustav aktiivne enesejuhitud õppimisviis enamikule suhteliselt võoras (Lea et al., 2003; Pilli, Sammul, Post, Aasjõe, \& Kruusamäe, 2013; Roosalu et al., 2013). Õppimisviisidest eelistavad üliõpilased pigem passiivset loengus osalemist (Vadi et al., 2014), kus nad on peamiselt kuulaja rollis. Samas näevad üliõpilased, et õppejõu roll on toetada üliõpilaste õppimist ning edastada õppematerjali aktiivsel ja innustaval viisil (Roosalu et al., 2013). Lea jt (2003) hinnangul on loomulik, et õppijate ettekujutus õppimisest on loengute kuulamine, sest ei olda harjutud õppima teisiti.

Eesti täiskasvanud õppija uuringust ilmnes, et õppijad ei pea õppijakeskset lähenemisviisi ega isiklike õpieesmärkide saavutamist oluliseks (Roosalu et al., 2013). See võib olla tingitud asjaolust, et küllaltki paljudel õppijatel lastakse olla mugavustsoonis, mistõttu ei toimu ka muutusi ega ülemäärast pingutust õppimises (Vadi et al., 2014). Ülikoolide ja rakenduskõrgkoolide uuringust selgus, et õppimisest hoidumine võib aga olla põhjustatud madalatest enesekohastest hinnangutest. Neid tulemusi ei saa võtta kergel käel, sest enesehinnangulistel uskumustel on mõju akadeemilisele edukusele (Täht, Adov, Mägi, \& Must, 2013). 
Samas ei saa õppijakeskse lähenemisviisi rakendumisel lähtuda ainult õppijate valmisolekust ja oskustest. Esmakursuslaste ja täiskasvanud õppijate uuringust selgus, et õppijatel ei ole olnud piisavalt võimalusi valida õpiülesandeid, mis neile huvi pakuksid (Roosalu et al., 2013). Need tulemused viitavad, et õppimisse aktiivseks panustamiseks ja motivatsiooni tagamiseks ning ennastjuhtiva õppija kujunemiseks ei ole üliõpilastel soodsat keskkonda. Teisalt aga võib põhjuseid otsida õpetamise käsitustest, mis mõjutavad õpetamise eesmärke õppija- või õppejõukeskse lähenemisviisi suunas (Lea et al., 2003; Postareff \& Lindblom-Ylänne, 2008). Lea jt (2003) uuringu kohaselt on üliõpilastel kõrgkoolis toimuvate muudatustega lihtsam kaasa minna, kui nad on algusest alates õppeprotsessi loomisesse kaasatud kui partnerid, keda toetatakse uute õppimisviiside rakendamisel ja kellele võimaldatakse kahesuunalist tagasisidet.

Eespool esitatud uurimistulemuste põhjal võib öelda, et üleminek väljundipõhisele õppele ei ole oma eesmärgi kohaselt (õppija individuaalse arengu maksimaalne toetamine) veel rakendunud. Õppijakesksele õppele üleminekul tasub Udami jt (2015) hinnangul keskenduda muutuste kvaliteedile. Rutiku jt (2009) lisavad, et muutuste edukust saab tagada siis, kui sellesse panustavad kõik osalised: nii üliõpilased, õppejõud kui ka kõrgkool.

\section{Õppimisse kaasatus}

Õppijakeskne lähenemine õpetamisele toetab õppijate panust ning kaasatust õppimisse (Rytkönen, Parpala, Lindblom-Ylänne, Virtanen, \& Postareff, 2012; Zepke, Leach, \& Butler, 2014). Õppimisse kaasatus (ingl student engagement) mõjutab omakorda üliõpilase õpistrateegiaid, õppimise tulemuslikkust ja väljundeid (Carini, Kuh, \& Klein, 2006; Rytkönen et al., 2012). Kuh' (2001, 2009) hinnangul kasutatakse õppimisse kaasatuse terminit enamasti siis, kui räg̈gitakse õppimisse panustamise kvaliteedist (aeg ja energia, mida õppija investeerib eesmärgipäraste tegevuste elluviimisse) ning produktiivsetesse õpitegevustesse kaasatusest (kõrgkoolide pühendumine efektiivsete õpitegevuste kasutamisele).

Kõrgkooli kontekstis on õppimisse kaasatus institutsionaalsete tegurite ja õppija karakteristikute kogum, mille väljund on individuaalne psühholoogiline seisund ehk kaasatud õppija (Baron \& Corbin, 2012; Kahu, 2013). Lisaks on õppimisse kaasatus situatiivne ning see võib konteksti ja indiviidi koosmõjus õppeprotsessis aineti varieeruda (Kahu, 2013). Kaasatus ei ole ainult ühepoolne protsess. See on kõrgkooli kui õpikeskkonna, õppejõudude ja üliõpilaste interaktsiooni tulemus (Nystrand \& Gamoran, 1991; Zepke et al., 2014). Zepke jt (2014) uuringust selgus, et õppejõudude ja üliõpilaste õppimisse kaasatuse aru- 
saamades on nii sarnasusi kui ka erinevusi. Õppijatel kipuvad olema suured ootused õppe suhtes. Õppejõud on nendest ootustest enamasti teadlikud, kuid nad ei pruugi olla teadlikud sellest, kui oluliselt nende tegevused mõjutavad õppijate kaasatust õppimisse.

Kuigi õppimisse kaasatust on laialdaselt uuritud, ei ole tänapäevani saavutatud üksmeelt kaasatuse käsitustes (Baron \& Corbin, 2012) ning ei suudeta eristada tegureid, mis mõjutavad õppija kaasatuse lühi- ja pikaajalisi tulemusi (Kahu, 2013). Kahu (2013) järgi võib õppimisse kaasatuse uuringutes eristada nelja lähenemisviisi:

1) käitumuslik, milles keskendutakse õppija käitumisele ja efektiivsetele õpetamistegevustele;

2) psühholoogiline, milles käsitletakse õppimisse kaasatust kui individuaalset ja sisemist protsessi;

3) sotsio-kultuuriline, kus keskendutakse konteksti olulisusele;

4) holistiline, milles püütakse koondada eelnenuid üheks tervikuks.

Praeguses uurimuses keskendutakse käitumuslikule ja psühholoogilisele kaasatusele. Psühholoogilise kaasatusena käsitletakse sisemisi psühholoogilisi protsesse, mis on pidevas muutumises ja mille intensiivsus varieerub. Psühholoogilise kaasatuse puhul eristatakse tunnetuslikku ning seotust, emotsioone ja tungi väljendavat dimensiooni. Tunnetuslik dimensioon hõlmab õppija eneseregulatsiooni ja tõhusate õppimisviiside kasutamist (Fredricks, Blumenfeld, \& Paris, 2004). Seotuse dimensioon hõlmab positiivset kõrgkooli reeglite järgimist, õppetöös ja õppekavavälistes tegevustes osalemist ning õppimisse kaasatust (ibid.). Emotsioonide dimensiooni korral on õppija motiveeritud, kui ta tunneb rahulolu ja huvi õppimise vastu. Tungi dimensioon kätkeb õppija tahet õnnestuda. Enamasti on psühholoogiline kaasatus lõiming eespool mainitud dimensioonidest. Psühholoogilise kaasatuse tunnetusliku dimensiooni elementide kaudu on mõnel puhul kirjeldatud ka käitumuslikku kaasatust (Kahu, 2013).

Käitumuslik kaasatus väljendub õppetegevustes osalemisena (Gunuc \& Kuzu, 2015). Seda mõjutavad nii kõrgkoolide tavad, õppija õppimine kui ka õppejõu õpetamine, mis on seotud õppija rahulolu ja saavutustega, nagu näiteks ülesandele kulunud aeg ning sotsiaalne ja akadeemiline suhtlus. Käitumuslikku kaasatust iseloomustab ka distaalne vaade, näiteks asjaolu, kuidas üliõpilaste õpingute aeg on toetanud neil eluks vajalike laiemate oskuste omandamist, nagu eri rahvuste, kultuuride mõistmine, isiklikud väärtused, panus nii ühiskonda kui ka selle heaolusse (Kahu, 2013).

Kaasatus on konstrukt, mida mõjutavad paljud tegurid. Praeguses uurimuses on tähelepanu all õppeprotsessi tegurid (õpiväljundite arusaadavus, keskkond, õpetamine, õppematerjalid, tagasiside, tööde maht, hindamisülesanded, 
sooritatud tööd), õppija motivatsioon ja rahulolu, millest lähtudes püütakse selgitada psühholoogilise ja käitumusliku kaasatuse hinnanguid.

Siinse uurimuse kontekstis osutus probleemseks kaasatuse mõistele eestikeelse vaste leidmine, sest kaasatusele saab läheneda mitmeti ja seetõttu sobib kasutada eri termineid. Kokkuleppeliselt kasutatakse siinkohal käitumusliku kaasatuse puhul vastet óppimisse panustamine (väide „Valmistusin hoolikalt loenguteks ja seminarideks, et võtta nendest maksimum") ning psühholoogilise kaasatuse puhul terminit õppimisse kaasatus (väide „Mõtlesin, kuidas saaksin kursusel tõhusamalt õppida"). Nii on siinses töös kaasatuse mõistet, mida inglise keeles märgib termin engagement, tähistatud sisulise täpsuse huvides kahe eestikeelse terminiga.

Et toetada õppijakeskse õpikäsituse rakendumist väljundipõhise õppe abil, on oluline uurida üliõpilaste ja õppejõudude kogemusi ning välja selgitada, millised on üliõpilaste ja õppejõudude hinnangud õpiväljundite saavutamist toetavatele õppekomponentidele ning milline on õppijate motivatsioon, kaasatus ja valmisolek osaleda väljundipõhises õppes. Seetõttu on praeguse uurimuse eesmärk välja selgitada, kuidas õppejõud ja üliõpilased hindavad väljundipõhise õppe rakendumist õpiväljundite omandamist toetavate komponentide, sh kaasatuse kaudu. Tööd raamivad järgmised uurimisküsimused.

1. Kuidas hindavad üliõpilased ja õppejõud õpiväljundite saavutamist toetavaid õppekomponente, õppijate motivatsiooni, õppimisse kaasatust, õppimisse panustamist ning rahulolu läbitud kursusega?

2. Millised mustrid ilmnevad üliõpilaste ja õppejõudude hinnangutes õppimisse panustamise ja kaasatuse ning õpiväljundite omandamist toetavate õppekomponentide, õppijate motivatsiooni ja rahulolu vahel?

\section{Metoodika}

Praegune uuring on osa suuremast uurimusest, mille eesmärk on hinnata väljundipõhise õppe rakendumist kombineeritud disainiga eVALUate'i tagasisideküsimustiku abil, mis peegeldab üliõpilaste õppimist ja õpiväljundite saavutamist (Oliver, Tucker, Gupta, \& Yeo, 2008). Enne uuringut on eVALUate'i tagasisideküsimustikku kohandatud ja valideeritud Eesti konteksti arvestades ning tehtud üliõpilaste hinnangute analüüs, mille kohaselt hinnatakse madalaimalt õppimisse kaasatust ja panustamist (Kumpas-Lenk, Tucker, \& Gupta, 2014). Praegune uuring keskendub kvantitatiivselt kogutud andmete analüüsile ning eelnenud analüüsi tulemustest lähtuvalt on artikli fookuses väljundipõhise õppe rakendajate ehk üliõpilaste ja õppejõudude hinnangud õpiväljundite omandamist toetavatele komponentidele ning nende komponentide seosed õppijate õppimisse kaasatuse ja panustamise hinnangutega. 
eVALUate'i originaalinstrumendis esitatud kaasatuse väidete sisu paremaks edasiandmiseks ning täpsemate eestikeelsete vastete leidmiseks analüüsiti neid Kahu (2013) kaasatuse kontseptsioonide mudeli alusel, võrreldes seejuures väite sisu ühtivust Kahu mudelis kirjeldatuga. Väidete sisuanalüüsist selgus, et valideeritud instrument võimaldab välja selgitada kaasatuse käitumuslikku ja psühholoogilist (tunnetuslikku) poolt.

\section{Valim}

Uuringus osalemise kutse saadeti 3669 üliõpilasele ja 113 õppejõule. Üliõpilastelt koguti 1329 analüüsiks sobilikku vastust (vastamise protsent 36,2) ja õppejõududelt 94 vastust (vastamise protsent 83,5). Uurimuse valimi moodustasid bakalaureusetaseme kursuste üliõpilased ja õppejõud kuue Eesti kõrgkooli (kolme rakenduskõrgkooli, kolme ülikooli) kaheksast teaduskonnast või osakonnast (valdkondadest majandus, kunst, tervis ja sotsiaalia). Mitmekesise ja eesmärgipärase valimi tagamiseks paluti uuringusse kaasatud teaduskondade või osakondade kontaktisikutel nimetada igalt õppekavalt erinevaid kursusi (õppeaineid), mille valiku aluseks olid järgmised põhimõtted:

1) osalejate arv: üle 50 üliõpilase ja alla 50 üliõpilasega kursused;

2) õppevorm: nii päeva-, kaug- kui ka õhtuõpe;

3) bakalaureusetaseme kursused;

4) üld- ja erialaained;

5) õppe valdkond (vastavalt uuringus osalevale teaduskonnale või osakonnale). Kuna uuring toimus paralleelselt kõrgkoolides läbiviidavate ainepõhiste tagasisideküsitlustega, siis valimi moodustamisel jälgiti, et ükski üliõpilane ei peaks andma tagasisidet rohkem kui nelja kursuse kohta.

\section{Mõõtevahend}

Eesti konteksti kohandatud ja valideeritud eVALUate'i instrument, mida kasutati uuringus, on loodud ülikooli kvaliteedihindamissüsteemi osana eesmärgiga saada ainetepõhist tagasisidet üliõpilaste õpiväljundite omandamist mõjutavate komponentide kohta. eVALUate'i instrument võimaldab tagasisidet koguda nii õppeprotsessi, motivatsiooni, rahulolu kui ka õppimisse panustamise ja kaasatuse kohta. Instrumendi õppeprotsessi kvaliteedi hindamise (õpiväljundite arusaadavuse, keskkonna, õpetamise, õppematerjalide, tagasiside, tööde mahu, hindamisülesannete, sooritatud tööde), motivatsiooni, rahulolu ja kaasatuse komponentide väljatöötamisel toetusid eVALUate’i autorid mitmetele motivatsiooni-, enesetõhusus-, kaasatus- ja rahuloluteooriate loojate töödele, nt Archer jt, Bandura, Candy jt, Coates, Entwistle, Fenwick, Kuh, Pintrich jt, Ramsden, Schunk, Scott, Zhao (Oliver et al., 2008). 
eVALUate koosneb nii avatud kui ka suletud küsimustest. Praegune uuring keskendus kvantitatiivsele osale (11 küsimust), kus üliõpilaste ja õppejõudude hinnangutest lähtudes selgitatakse välja, millised õppeprotsessi komponendid toetavad üliõpilaste õpiväljundite saavutamist (küsimused 1-7), milline on õppijate motivatsioon (küsimus 8) ja rahulolu (küsimus 11) ning millised on hinnangud õppija panusele ja kaasatusele õppimisse (küsimused 9-10). Iga küsimuse all oli kaldkirjas esitatud küsimust selgitav tekst (vt lisa 1).

Nii üliõpilased kui ka õppejõud vastasid samale küsimustikule, kuid õppejõudude ülesanne oli vastata küsimustele õppijatest lähtudes ehk selgitada, kuidas nende hinnangul õppijad õppisid. Igale küsimusele oli võimalik anda hinnanguid viiepunktisel Likerti skaalal.

eVALUate'i instrumendi valideerimisel Eesti konteksti kasutati Raschi analüüsi, millest selgus, et küsimustiku hinnangute skaala töötab ning küsimused mõõdavad õppimise ja õpetamise eri komponente. Väidete reliaabluse määramiseks leitud Cronbachi alfa värrtus $(\alpha=0,92)$ näitas, et tegemist on usaldusväärse instrumendiga, mida omakorda kinnitas kõrgkoolidepõhine lisaanalüüs (Kumpas-Lenk et al., 2014).

\section{Protseduur}

Uuringu eel lepiti kõrgkoolidega kokku uuringu valim ja plaan ning kõrgkooli kontaktisik, kes edastas uurijale uuringu tegemiseks vajalikud andmed (kursuste nimed, õppejõudude nimed, kursuste mahud, õpiväljundid, kursustel osalenud üliõpilaste kontaktandmed). Uuring tehti elektroonilises keskkonnas LimeSurvey, mille kaudu edastati kursuse lõppemise järel umbes ühe nädala jooksul üliõpilaste ja õppejõudude e-posti aadressile uuringus osalemise kutse. See sisaldas infot selle kohta, et uuringus osalemine on vabatahtlik ja saadud andmeid kasutatakse vaid üldistatud kujul. Küsimustik oli vastamiseks avatud kolm nädalat ja selle aja jooksul saadeti mittevastanutele meeldetuletusi uuringus osalemise kohta. Vastamisperioodi järel koostati kõrgkoolidele ja õppejõududele üldistatud andmetega koondid. Nende kursuste kohta, kus vastanuid oli vähem kui kolm, koondeid ei koostatud, et tagada üliõpilaste vastuste anonüümsus.

\section{Andmeanalüïs}

Juhindudes eVALUate'i originaalinstrumendi autorite analüüsimissuundade soovitustest (Oliver et al., 2008), arvutati uuringus osalevate kõrgkoolide õppejõudude ja üliõpilaste arvamuste kõrvutamiseks nõusolekut väljendavate hinnangute (hinnangud „Täiesti nõus“ ja „Pigem nõus“) kogusumma protsent. Oliveri jt (2008) uuringu kohaselt vajavad alla 80\% jäävad hinnangud tähele- 
panu, mistõttu on need andmed esile tõstetud (vt tabel 1). Edaspidises analüüsis eemaldati skaalapunkti „Ei oska öelda“ hinnangud ning seetõttu kasutati analüüsimiseks neljapunktist Likerti skaalat, kus 1 - „Ei ole nõus“ ja 4 - „Täiesti nõus“. Andmeid töödeldi statistikapaketiga SPSS 23.0. Õppejõudude ja üliõpilaste hinnangute vaheliste statistiliselt oluliste erinevuste väljaselgitamiseks kasutati mitteparameetrilist Mann-Whitney U-testi. Testi tulemustest ilmnenud erinevuste illustreerimiseks esitati väidete keskmised ja risttabelid. Et selgitada õppimisse panustamise ja kaasatuse ning teiste õpiväljundite omandamist toetavate komponentide vahelisi seoseid, tehti regressioonanalüüs Backwardmeetodil.

\section{Tulemused}

Üliõpilaste ja õppejõudude hinnangute kohaselt (vt tabel 1) toetavad õpiväljundite saavutamist järgmised õppeprotsessi komponendid: õpiväljundite selgus, õppetöö maht, õppematerjalid, õpikeskkond, sooritatud tööd, hindamisülesanded, õpetamine ja tagasiside. Samuti ilmnes, et üliõpilased olid enamasti motiveeritud õppima ja rahul kursusel saadud õpikogemusega. Seevastu hinnangud üliõpilaste enese panusele ja kaasatusele õppimisse (väited „Valmistusin hoolikalt loenguteks ja seminarideks, et võtta nendest maksimum“; „Mõtlesin, kuidas saaksin kursusel tõhusamalt õppida") olid võrreldes teiste hinnangutega madalamad (vahemik 69,2-76,0\%).

Tabel 1. Õppejõudude ja üliõpilaste hinnangud õpiväljundite saavutamist toetavatele komponentidele

\begin{tabular}{|c|c|c|c|c|c|c|c|c|c|c|c|c|}
\hline & \multicolumn{8}{|c|}{ Õppeprotsessi komponendid } & \multirow{2}{*}{ 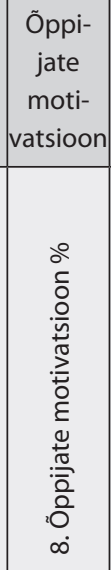 } & \multirow{2}{*}{ 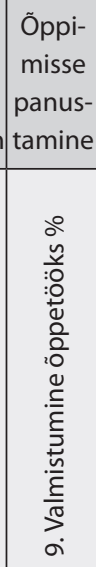 } & \multirow{2}{*}{ 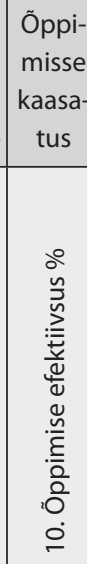 } & \multirow{2}{*}{ 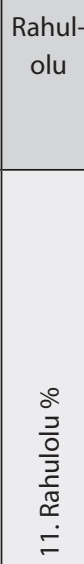 } \\
\hline & 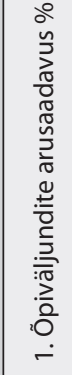 & 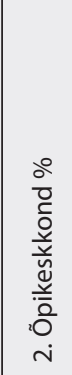 & 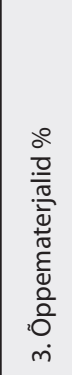 & 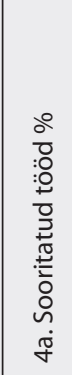 & 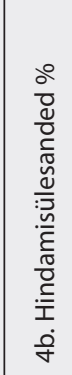 & 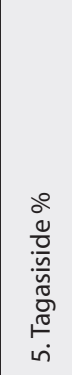 & 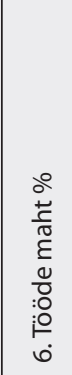 & 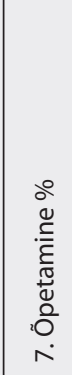 & & & & \\
\hline Üliõpilased & 90,1 & 90,9 & 90,2 & 90,4 & 88,0 & 81,9 & 85,9 & 89,2 & 86,5 & 76,0 & 71,6 & 86,9 \\
\hline Õppejõud & 94,7 & 93,6 & 96,8 & 95,7 & 92,6 & 91,5 & 79,8 & 95,7 & 91,5 & 69,2 & 71,3 & 83,0 \\
\hline
\end{tabular}


Mann-Whitney U-testi tulemustest selgus, et õppejõudude ja üliõpilaste hinnangute vahel on statistiliselt olulised erinevused hindamisülesannetes $(p=0,025 ; U=48741)$, õppijate motivatsioonis $(p=0,003 ; U=49301)$ ja rahulolus $(p=0,042 ; U=47719)$. Ülejäänud õpiväljundite saavutamist toetavate komponentide poolest ei erinenud õppejõudude ja üliõpilaste hinnangud statistiliselt olulisel määral. Õppejõudude ja üliõpilaste hinnangute erinevuste illustreerimiseks koostati risttabel (vt tabel 2).

Tabel 2. Erinevused õppejõudude ja üliõpilaste hinnangutes

\begin{tabular}{l|c|c|c|c}
\hline & $\begin{array}{c}\text { Täiesti } \\
\text { nõus \% }\end{array}$ & $\begin{array}{c}\text { Pigem } \\
\text { nõus \% }\end{array}$ & $\begin{array}{c}\text { Pigem ei ole } \\
\text { nõus \% }\end{array}$ & $\begin{array}{c}\text { Ei ole } \\
\text { nõus \% }\end{array}$ \\
\hline Üliõpilased & & & & \\
\hline Hindamisülesanded & 55,4 & 36,9 & 5,5 & 2,2 \\
\hline Õppijate motivatsioon & 52,0 & 36,3 & 8,1 & 3,6 \\
\hline Rahulolu & 49,6 & 38,8 & 8,0 & 3,6 \\
\hline Õppejõud & & & & \\
\hline Hindamisülesanded & 65,9 & 33,0 & 0,0 & 1,1 \\
\hline Õppijate motivatsioon & 29,7 & 64,8 & 4,4 & 1,1 \\
\hline Rahulolu & 32,5 & 61,4 & 6,0 & 0,0 \\
\hline
\end{tabular}

Analüüsist järeldub, et õppejõudude hinnangud hindamisülesannetele $(M=3,64)$ on kõrgemad kui üliõpilastel $(M=3,45)$. Samas hindavad üliõpilased enda motivatsiooni õppida kõrgemalt $(M=3,37)$ kui õppejõud $(M=3,23)$ ning üliõpilaste hinnangul on nad läbitud kursusega rahulolevamad $(M=3,34)$, kui õppejõud seda arvavad $(M=3,27)$.

Kuna tabeli 1 andmetest selgus, et nii üliõpilaste kui ka õppejõudude hinnangud õppimisse panustamisele ja kaasatusele on võrreldes teiste näitajatega madalamad, leiti regressioonanalüüsi toel, mis tunnused kirjeldavad ja prognoosivad õppija panuse ning kaasatuse väärtusi. Seejuures tehti regressioonanalüüs eraldi nii õppejõudude kui ka üliõpilaste valimi põhjal. Sõltuvate tunnuste (õppimisse panustamise ja õppimisse kaasatuse) seosed sõltumatute tunnustega (kõik ülejäänud muutujad) on esitatud tabelites 3 ja 4. 
Tabel 3. Õppimisse panustamise hinnangute seosed õpiväljundite omandamist toetavate teguritega

\begin{tabular}{l|c|c|l|c|c}
\hline \multicolumn{2}{l}{ Üliõpilased, $R^{2}=0,380$} & \multicolumn{4}{l}{ Õppejõud, $R^{2}=0,661$} \\
\hline Muutujad & $\beta$ & $p$ & Muutujad & $\beta$ & $p$ \\
\hline Õppimisse kaasatus & 0,421 & 0,000 & Õppimisse kaasatus & 0,507 & 0,000 \\
\hline Õppijate motivatsioon & 0,264 & 0,000 & Tööde maht & 0,309 & 0,002 \\
\hline Tööde maht & 0,112 & 0,000 & Õpikeskkond & 0,182 & 0,031 \\
\hline & & & Õppijate motivatsioon & 0,179 & 0,082 \\
\hline & & & Hindamisülesanded & $-0,186$ & 0,053 \\
\hline
\end{tabular}

Determinatsioonikordaja põhjal saab üliõpilaste hinnangutest lähtudes väita, et õppimisse kaasatuse, õppijate motivatsiooni ja tööde mahu tulemustega on võimalik kirjeldada ligikaudu $38 \%$ üliõpilaste õppimisse panustamise komponendi tulemuste variatiivsusest $\left(R^{2}=0,380, F=0,349, p<0,001\right)$. Õppejõudude mudeli muutujad ühtivad osaliselt üliõpilaste mudeli omadega: $66 \%$ ulatuses õppejõudude tajutud üliõpilaste õppetöösse panustamise hinnangute variatiivsusest $\left(R^{2}=0,661, F=0,220, p<0,001\right)$ ennustavad peamiselt üliõpilaste õppimisse kaasatus, tööde maht ja õpikeskkond. Väiksemate osakaaludega muutujate tulemused on toodud tabelis 3 .

Tabel 4. Õppimisse kaasatuse hinnangute seosed õpiväljundite omandamist toetavate teguritega

\begin{tabular}{l|c|c|l|c|c}
\hline Üliõpilased, $R^{2}=0,328$ & \multicolumn{3}{l}{ Õppejõud, $R^{2}=0,644$} & \\
\hline Muutujad & $\beta$ & $p$ & Muutujad & $\beta$ & $p$ \\
\hline Õppimisse panustamine & 0,459 & 0,000 & Õppimisse panustamine & 0,456 & 0,000 \\
\hline Õppijate motivatsioon & 0,124 & 0,000 & Õppijate motivatsioon & 0,270 & 0,007 \\
\hline Rahulolu & 0,111 & 0,005 & Rahulolu & 0,243 & 0,005 \\
\hline Õpiväljundite arusaadavus & 0,098 & 0,003 & & & \\
\hline Tagasiside & 0,080 & 0,021 & & & \\
\hline Õppematerjalid & $-0,096$ & 0,005 & & & \\
\hline Õpetamine & $-0,085$ & 0,031 & & & \\
\hline Tööde maht & $-0,075$ & 0,016 & & & \\
\hline
\end{tabular}


Determinatsioonikordaja põhjal saab väita, et õppetöösse panustamise, õppijate motivatsiooni ja rahulolu väidete tulemustega on võimalik kirjeldada üliõpilaste óppimisse kaasatuse tulemuste variatiivsusest $\left(R^{2}=0,328, F=0,144\right.$, $p<0,001$ ) ligikaudu 33\% ja õppejõudude hinnangutega üliõpilaste õppimisse kaasatusele ligikaudu $64 \%\left(R^{2}=0,644, F=0,151, p<0,001\right)$. Nii óppejõudude kui ka üliõpilaste hinnangute regressioonimudelitest selgus, et õppimisse kaasatuse komponendi peamisteks kirjeldajateks on õppimisse panustamise, õppijate motivatsiooni ja rahulolu hinnangute tulemused. Õppimisse kaasatuse hinnangutega seotud sõltumatute muutujate terviklik nimekiri ja tulemused on toodud tabelis 4 .

\section{Arutelu}

Üliõpilaste ja õppejõudude hinnangute kohaselt toetab väljundipõhine õppeprotsess üliõpilastel õpiväljundite saavutamist, lisaks on üliõpilased motiveeritud õppima ja rahul õppeainetes saadud õpikogemustega. Seevastu hinnangud üliõpilaste enese panusele ja kaasatusele õppimisse olid võrreldes teiste hinnangutega madalamad, mis viitab, et väljundipõhine õpe ei täida praegu veel oma eesmärki toetada õppijakeskse lähenemisviisi rakendamist. Ka teised uuringud kinnitavad, et üliõpilased on motiveeritud ja rahul oma õpingutega, kuid ei panusta piisaval määral sellesse, et nad oleksid kaasatud ning võtaksid ise aktiivse rolli ja vastutuse oma õppimise eest (Pilli et al., 2013; Postareff \& Lindblom-Ylänne, 2008; Roosalu et al., 2013; Rutiku et al., 2009; Udam et al., 2015; Vadi et al., 2014).

Üliõpilaste kaasatuse, koostöö ja akadeemilise edasijõudmise tagamiseks on oluline alustada õppijate toetamist ülikooliõpingute esimesest päevast alates (Rytkönen et al., 2012). Kuh' jt (2008) soovitusel peaksid õppejõud andma õppijatele rohkem ülesandeid, mis nõuavad neilt vastutuse võtmist. Suurem vastutus igapäevastes tegevustes haarab õppijaid õppimisse, nad väärtustavad seda, millesse on aega panustanud, ja seega pühenduvad rohkem õppimisele. Peale õppijatele vastutuse andmise rõhutab Kahu (2013), et oluline on suurendada nende teadlikkust erinevatest muutujatest, mida nad saavad ise kontrollida, et olla rohkem kaasatud. Roosalu jt (2013) täiendavad seda seisukohta väitega, et óppijate isiklike õpieesmärkide seadmisele ja saavutamisele tasub tähelepanu pöörata, toetamaks õppijakeskse lähenemisviisi edukamat rakendumist. Õppija autonoomia ja vastutus on nende soovituses kesksed märksõnad. Neid soovitusi kinnitab isemääramisteooria, mille raames määratletakse autonoomiat kui inimese tegutsemist oma tahte ja valikute kohaselt. Autonoomiale vastandub kontroll, kus välised jõud sunnivad inimest kindlal viisil käituma (Deci \& Ryan, 2013). 
Varasemad uuringud on näidanud, et õpetajate ja õppijate hinnangud õppimisele on nende arusaamade ja individuaalsete kogemuste tõttu erinevad (Virtanen \& Lindblom-Ylänne, 2010). Praegusse uuringusse kaasatud õppejõudude ja üliõpilaste hinnangute võrdlusest ilmnes, et need erinesid kolme õpiväljundite omandamist toetava komponendi poolest. Selgus, et üliõpilaste hinnangud õpiväljundite saavutamist toetavatele hindamisülesannetele olid madalamad kui õppejõududel. Samas hindasid üliõpilased enda motivatsiooni saavutada kursuse õpiväljundid ning rahulolu kursusega õppejõududest oluliselt kõrgemalt. Ülejäänud õpiväljundite omandamist toetavate komponentide puhul üliõpilaste ja õppejõudude hinnangud statistiliselt olulisel määral ei erinenud, mis viitab, et üliõpilaste kui õppijate kogemused ja õppejõudude kui õppeprotsessi juhtide kogemused on sarnased ning kinnitavad teineteise hinnanguid.

Nii õppejõudude kui ka üliõpilaste hinnangutest ilmnes, et õppetöösse panustamist prognoosib eelkõige õppijate kaasatus õppimisse, nende motivatsioon ja kursuse jooksul tehtud tööde maht. Õppimisse kaasatust ennustasid aga mõlemal rühmal õppijate panustamine õppimisse, õppijate motivatsioon ja rahulolu kursusega. Kahu (2013) kaasatuse mõjurite ja tulemuste kontseptsioonist lähtudes on need tulemused ootuspärased. Samuti kinnitavad varasemad uuringud kaasatuse tugevat seost nii kaasatuse eri dimensioonide, õppijate motivatsiooni, rahulolu kui ka tööde mahu ja õppetööks valmistumisega (ibid.). Seega tasub õppimisse panustamisel ja kaasatuse tõhustamisel pöörata tähelepanu just eespool välja toodud aspektidele. Et suurendada õppijate kaasatust ja õppimisse panustamist ning välja selgitada takistavad põhjused, soovitame uurida kaasatust kui terviklikku konstrukti.

\section{Kokkuvõte}

Juba mõnda aega on väljundipõhist õpet Eesti kõrgkoolides rakendatud, sh on õppekavad ja kursuseprogrammid väljunditele üles ehitatud, kuid see ei anna alust väita, et sellega on toimunud paradigmaatiline üleminek väljundipõhisele ehk õppijakesksele õppeprotsessile. Kuigi praegusest uuringust selgus, et õppimisse kaasatus ja panustamine on aspektid, mis väljundipõhise õppe juures vajavad tähelepanu, siis tuginedes Carini jt (2006) uurimusele, tasub silmas pidada, et õppimist väljundipõhises õppes tuleb vaadelda tervikuna.

Saadud tulemuste ja loetud kirjanduse põhjal saab esile tuua kaks peamist küsimuste ringi. Esimene seostub õppejõudude ja institutsionaalse kontekstiga, kus õppejõud töötab. Nagu näitab ka praegune uuring, vajab õppija vajadustest lähtuva õppeprotsessi kujundamine, kus kõik õppeprotsessi komponendid (õpiväljundid, eesmärgid, ülesanded, iseseisvad tööd, õpetamine, tagasiside, hindamine) on omavahel kooskõlas, laiemat tähelepanu. Suure mõjuga on 
kõrgkooli kultuur, õigusaktid, õppejõudude töökorraldus ja tunnustamine. Kuigi Eesti kõrgkoolide õppejõududel on olnud eri programmide raames palju koolitusvõimalusi, peab koolitusega kaasnema ka tugi omandatud teadmiste rakendamiseks. Siinkohal on toimunud edasiminekuid, näiteks on kõrgkoolides sõlmitud õpetamisprintsiipide kokkuleppeid, kujunenud on õppejõudude õpirühmad, kes vastastikku üksteise loengutes osalevad ja tagasisidet annavad. Muutused õpikäsituses toimuvad siis, kui enamik õppejõude lähtub õppe kavandamisel üliõpilastest, kuid selles protsessis ei saa õppejõudu üksi jätta.

Üks kriitilisemaid küsimusi on hindamine, milles ka õppejõudude ja üliõpilaste hinnangud korraldatud uuringus oluliselt erinesid. Väljundipõhises õppes on hindamine aga veelgi keerulisem. Õppejõul tuleb õpiväljundi põhjal otsustada, kuidas ja milliste meetodite toel määratud väljundit hinnata, ning alles seejärel saab ta kindlaks määrata hindamiskriteeriumid. Üks võimalus on kujundada hindamismeetodid ja -kriteeriumid üliõpilastega koos. See aitab ennetada üliõpilastepoolseid arusaamatusi hindamiskriteeriumite tõlgendamisel, aga annab ka õppejõududele kindluse, et üliõpilased on hindamiskriteeriumitest teadlikud ning seetõttu rohkem valmis õppesse panustama.

Teine küsimuste ring on seotud üliõpilaste ja nende valmidusega võtta enda õppimise eest vastutust ning panustada ise oma õppimise planeerimisse ja iseseisvalt õppida. Selleks peavad üliõpilastel kujunema vajalikud õpioskused, algatusvõime, ettevõtlikkus jt oskused, mis on seotud eneseregulatsiooni ja -tõhususega. Erinevalt varasemast peaks tänapäeva õpikeskkond võimaldama õppijal võtta suuremat vastutust ning pakkuma rohkem võimalusi oma õppimisvalikute üle otsustada. Õppeprotsess peaks olema paindlikum, et õppija saaks teha enda õppimist toetavaid valikuid, sest autonoomsed óppijad on valmis ise rohkem panustama. Õppimisse panustamist ja kaasatust saaks suurendada sellega, kui võimaldada üliõpilastel seada õppejõu määratud õpiväljunditele lisaks iseenda jaoks olulisi õpiväljundeid ja nendest lähtuvaid ülesandeid, mis toetavad väljundi saavutamist. Sealhulgas peaksid üliõpilased regulaarselt hindama ja tõhustama oma õppimist, mille soosimiseks võib kasutusele võtta õpianalüütika vahendeid, mis võimaldavad õppijal koguda tagasisidet enda õppeprotsessi panustamise kohta ja õppejõul saada ülevaadet õppija arengust.

Praegusel uuringul on ka mitmeid piiranguid, mida tasub edaspidi arvesse võtta. Esmalt, tulemuste üldistamisel on vaja silmas pidada, et õppimisse kaasatus on distsipliiniti kvalitatiivselt erinev (Brint, Cantwell, \& Hanneman, 2008), mistõttu distsipliinideülesed instrumendid ei pruugi viia soovitud tulemusteni (Kahu, 2013). Uuringus kasutatud kursuse tagasiside küsimustik võimaldab saada ülevaadet õppe komponentidest, mis toetavad õpiväljundite omandamist, ning anda tagasisidet komponentide kohta, millele tuleb tähele- 
panu pöörata. Teisalt tuleb siiski arvestada, et õppimisse kaasatuse kohta terviklike järelduste tegemiseks ei piisa vaid kahe kaasatuse aspekti uurimisest, sest kaasatusele peaks selle dünaamilise ja situatiivse seisundi tõttu lähenema sügavuti (Kahu, 2013). Õppimisse kaasatuse põhjalikumaks uurimiseks tuleks järgnevalt kasutada kvalitatiivseid meetodeid, mis võimaldavad tabada õppijate kogemuste mitmekesisust. Samuti tasub kaaluda pikiuuringuid, kui soovitakse mõista õppimisse kaasatuse dünaamikat. Kuna kõrgkooli kontekstil on õppimisse kaasatusele oma mõju (Baron \& Corbin, 2012; Rutiku et al., 2009), siis selleks, et tõhustada konkreetses kõrgkoolis õppija kaasatust, tuleks uurida selle institutsiooni eri tegureid, nagu õppekavade ülesehitus, õppeprotsessi korraldus, õppejõudude arengu toetamine.

Kahu (2013) kontseptsioonile tuginedes võib öelda, et õppija kaasatuse tõhustamiseks on mitmeid viise alates psühhosotsiaalsetest mõjuteguritest ja lõpetades kaudsete akadeemiliste tulemustega. Vastutus õppimisse kaasatuse eest lasub aga kõigil osalistel: nii üliõpilasel, õppejõul, kõrgkoolil kui ka konteksti loojal.

\section{Tänusõnad}

Artikli autorid soovivad tänada Anna-Liisa Jõge, kes aitas mõtestada andmeanalüüsiga seonduvat.

\section{Kasutatud kirjandus}

Adam, S. (2008). Learning outcomes current developments in Europe: Update on the issues and applications of learning outcomes associated with the Bologna process. Retrieved from http://www.ehea.info/cid103095/learning-outcomes-edinburghfebruary-2008.html.

Baron, P., \& Corbin, L. (2012). Student engagement: Rhetoric and reality. Higher Education Research \& Development, 31(6), 759-772. https://doi.org/10.1080/07294360.2012.655711

Barr, R. B., \& Tagg, J. (1995). From teaching to learning - A new paradigm for undergraduate education. Change: The Magazine of Higher Learning, 27(6), 12-26. https://doi.org/10.1080/00091383.1995.10544672

Biggs, J., \& Tang, C. (2009). Õppimist väärtustav õpetamine ülikoolis. Keskmes õppija tegevused. Tartu: Tartu Ülikooli Kirjastus.

Brint, S., Cantwell, A. M., \& Hanneman, R. A. (2008). The two cultures of undergraduate academic engagement. Research in Higher Education, 49(5), 383-402. https://doi.org/10.1007/s11162-008-9090-y

Carini, R. M., Kuh, G. D., \& Klein, S. P. (2006). Student engagement and student learning: Testing the linkages. Research in Higher Education, 47(1), 1-32.

https://doi.org/10.1007/s11162-005-8150-9 
Deci, E., \& Ryan, R. (2013). The importance of autonomy for development and wellbeing. In B. Sokol, F. Grouzet, \& U. Müller (Eds.), Self-regulation and autonomy: Social and Developmental dimensions of human conduct (pp. 19-46). Cambridge: Cambridge University Press. https://doi.org/10.1017/CBO9781139152198.005

Eesti elukestva óppe strateegia 2020 (2014). Tallinn: Haridus- ja Teadusministeerium. Külastatud aadressil https://www.hm.ee/et/elukestva-oppe-strateegia-2020.

Fredricks, J. A., Blumenfeld, P. C., \& Paris, A. H. (2004). School engagement: Potential of the concept, state of the evidence. Review of Educational Research, 74(1), 59-109. https://doi.org/10.3102/00346543074001059

Gunuc, S., \& Kuzu, A. (2015). Student engagement scale: Development, reliability and validity. Assessment \& Evaluation in Higher Education, 40(4), 587-610. https://doi.org/10.1080/02602938.2014.938019

Hadjianastasis, M. (2016). Learning outcomes in higher education: Assumptions, positions and the views of early-career staff in the UK system. Studies in Higher Education, 1-17. https://doi.org/10.1080/03075079.2016.1141402

Huba, M. E., \& Freed, J. E. (2000). Learner-centred assessment on college campuses: Shifting the focus from teaching to learning. Boston: Allyn and Bacon.

Hussey, T., \& Smith, P. (2008). Learning outcomes: A conceptual analysis. Teaching in Higher Education, 13(1), 107-115. https://doi.org/10.1080/13562510701794159

Kahu, E. R. (2013). Framing student engagement in higher education. Studies in Higher Education, 38(5), 758-773. https://doi.org/10.1080/03075079.2011.598505

Kuh, G. D. (2001). Assessing what really matters to student learning inside the national survey of student engagement. Change: The Magazine of Higher Learning, 33(3), 10-17. https://doi.org/10.1080/00091380109601795

Kuh, G. D. (2009). The national survey of student engagement: Conceptual and empirical foundations. New Directions for Institutional Research, 2009(141), 5-20. https://doi.org/10.1002/ir.283

Kuh, G. D., Cruce, T. M., Shoup, R., Kinzie, J., \& Gonyea, R. M. (2008). Unmasking the effects of student engagement on first-year college grades and persistence. The Journal of Higher Education, 79(5), 540-563. https://doi.org/10.1080/00221546.2008.11772116

Kumpas-Lenk, K. (in review). University students' learning experiences: Students and teachers' perceptions. Teaching in Higher Education.

Kumpas-Lenk, K., \& Eisenschmidt, E. (in review). Does the design of learning outcomes matter? Implications of Bloom's taxonomy. Higher Education.

Kumpas-Lenk, K., Tucker, B. M., \& Gupta, R. (2014). Validation of a unit evaluation survey for capturing students' perceptions of teaching and learning: A comparison among Australian and Estonian higher education students. Studies in Educational Evaluation, 43, 178-185. https://doi.org/10.1016/j.stueduc.2014.08.001

Kõrgharidusstandard (2008). Riigi Teataja I 2008, 57, 322. Külastatud aadressil https://www.riigiteataja.ee/akt/110072013075?leiaKehtiv.

Lea, S. J., Stephenson, D., \& Troy, J. (2003). Higher education students' attitudes to student-centred learning: Beyond 'educational bulimia'? Studies in Higher Education, 28(3), 321-334. https://doi.org/10.1080/03075070309293

Nystrand, M., \& Gamoran, A. (1991). Instructional discourse, student engagement, and literature achievement. Research in the Teaching of English, 25(3), 261-290. 
Oliver, B., Tucker, B., Gupta, R., \& Yeo, S. (2008). eVALUate: An evaluation instrument for measuring students' perceptions of their engagement and learning outcomes. Assessment \& Evaluation in Higher Education, 33(6), 619-630. https://doi.org/10.1080/02602930701773034

Pilli, E. (2009). Väljundipõhine hindamine kõrgkoolis. Tartu: Sihtasutus Archimedes.

Pilli, E., Sammul, M., Post, P., Aasjõe, Ü., \& Kruusamäe, K. (2013). Eesti kõrgkoolide esmakursuslaste õpi- ja teadmuskäsitus. Eesti Haridusteaduste Ajakiri, 1, 156-191. https://doi.org/10.12697/eha.2013.1.08

Pilli, E., \& Vanari, K. (2013). Defining the determining element of content mastery as the key aspect in congruence between learning outcomes and assessment. In E. Saar \& R. Mõttus (Eds.), Higher education at a crossroad: The case of Estonia (pp. 267-282). Frankfurt am Main: Peter Lang.

Postareff, L., \& Lindblom-Ylänne, S. (2008). Variation in teachers' descriptions of teaching: Broadening the understanding of teaching in higher education. Learning and Instruction, 18(2), 109-120. https://doi.org/10.1016/j.learninstruc.2007.01.008

Roosalu, T., Roosmaa, E-L., Lindemann, K., Reiska, E., Saar, E., Unt, M., ... Lang, A. (2013). Täiskasvanud óppijad Eesti kõrgharidussüsteemis. Kes püüab kõigest väest, saab üle igast mäest? Tartu: Sihtasutus Archimedes.

Rutiku, S., Valk, A., Pilli, E., \& Vanari, K. (2009). Õppekava arendamise juhendmaterjal. Tartu: Sihtasutus Archimedes.

Rytkönen, H., Parpala, A., Lindblom-Ylänne, S., Virtanen, V., \& Postareff, L. (2012). Factors affecting bioscience students' academic achievement. Instructional Science, 40(2), 241-256. https://doi.org/10.1007/s11251-011-9176-3

Zepke, N., Leach, L., \& Butler, P. (2014). Student engagement: Students' and teachers' perceptions. Higher Education Research \& Development, 33(2), 386-398. https://doi.org/10.1080/07294360.2013.832160

Tammets, K., \& Pata, K. (2013). The trends and problems of planning outcome-based courses in e-learning. In E. Saar \& R. Mõttus (Eds.), Higher education at a crossroad: The case of Estonia (pp. 283-303). Frankfurt am Main: Peter Lang.

Tina, A. (2008). Kahetsükliline kõrgharidus ehk 3+2 süsteem. H. Aru (toim.), Bologna protsess Eestis 2004-2008 (lk 13-17). Tartu: Sihtasutus Archimedes.

Täht, K., Adov, L., Mägi, M-L., \& Must, O. (2013). Does research-oriented university really have negative effect on students' self-evaluation? In E. Saar \& R. Mõttus (Eds.), Higher education at a crossroad: The case of Estonia (pp. 73-91). Frankfurt am Main: Peter Lang.

Udam, M. (2008). Lihtsalt mõistetavate ja võrreldavate kraadide süsteem. H. Aru (toim.), Bologna protsess Eestis 2004-2008 (lk 9-12). Tartu: Sihtasutus Archimedes.

Udam, M., Seema, R., \& Mattisen, H. (2015). Eesti kõrgharidus institutsionaalse akrediteerimise tulemuste taustal ehk Mida juhid peaksid teadma. Eesti Haridusteaduste Ajakiri, 3(1), 80-102. https://doi.org/10.12697/eha.2015.3.1.04

Vadi, M., Reino, A., \& Aidla, A. (2014). Õppejõud ja üliõpilane: rollikäsitluse vaade. Uuringu lõpparuanne. Tartu: Sihtasutus Archimedes.

Valk, A. (toim.) (2008). Bologna protsess Eestis 2004-2008. Tartu: Sihtasutus Archimedes. Külastatud aadressil http://www2.archimedes.ee/hkk/File/Erasmus/Bolog na+protsess+Eestis+2004+2008.pdf.

Virtanen, V., \& Lindblom-Ylänne, S. (2010). University students' and teachers' conceptions of teaching and learning in the biosciences. Instructional Science, 38(4), 355-370. https://doi.org/10.1007/s11251-008-9088-z 
Lisa 1. Eesti konteksti valideeritud eVALUate’i kursuse tagasiside küsimustik

Kirjeldava statistika jaoks paluti üliõpilastel nimetada oma õppevorm (päevane, õhtune, kaugõpe), sugu, vanus ja loengutes osalemise sagedus (mitte ühelgi, üksikutel, pooltel, enamikul, kõikidel) ning õppejõududel paluti nimetada oma vanus, sugu ja tööstaaž aastates.

Uuringu kvantitatiivses osas (küsimused 1-11) oli vastajail võimalik anda hinnanguid viiepunktisel Likerti skaalal: „Täiesti nõus“, „Pigem nõus“, „Pigem ei ole nõus“, „Ei ole nõus“, „Ei oska öelda“. Et lihtsustada küsimuste mõistmist, oli kaldkirjas esitatud küsimust selgitav tekst.

Palun hinda läbitud kursust järgmistest väidetest lähtudes. Väidete selgitused on toodud allpool.

1. Kursuse õpiväljundid olid selged ja arusaadavad.

Oppiväljundid kirjeldavad teadmisi, oskusi või hoiakuid, mida üliõpilane kursuse läbimise järel on omandanud (st teab, mõistab või oskab). Oodatavaid õpiväljundeid on kirjeldatud aineprogrammis ja õppejõud tutvustab neid kursuse alguses.

\section{2. Õpikeskkond toetas õpiväljundite omandamist.}

Õppe toimumise keskkonnaks võivad olla loengud, praktikumid, seminarid, e-õpe ja iseseisev õpe.

\section{Kursuse õppematerjalid toetasid õpiväljundite saavutamist.}

Óppematerjalid on näiteks paberil jaotusmaterjalid, multimeedia ja e-õppe materjalid, internetiallikad, raamatud, tehnilised vahendid.

\section{4a. Kursuse käigus sooritatud tööd toetasid õpiväljundite omandamist.}

Kursuse tööde all mõistetakse õppejõu antud ülesandeid, milleks võib olla iseseisev töö, grupitöö ja erinevad hindamisülesanded (eksam, arvestus jm).

\section{4b. Õppejõu antud ülesannetega hinnati õpiväljundite saavutatust.}

Hinnatavad ülesanded on need, mis lõpevad kas arvestuse, hinde või õppejõu tagasisidega, nt eksam, arvestustöö, kodutöö, grupitöö, kirjalik töö. Hindamiseks antud ülesanded mõõdavad otseselt üliõpilase ópiväljundite saavutatust.

\section{5. Õppejõu antud tagasiside toetas kursuse õpiväljundite omandamist.}

Tagasiside annab võimaluse saada informatsiooni ja hinnanguid tehtud tööle. Tagasiside võib olla nii kirjalik kui ka suuline.

\section{Kursuse jooksul tehtud töö maht oli õpiväljundite saavutamiseks piisav.}

Kursuse tööde alla võib lugeda kõik kursuse tarbeks tehtud tööd. See hõlmab auditoorseid loenguid, grupitöid, iseseisvat õppimist, hindamisega seotud ülesanded jne. 
7. Õpetamine toetas õpiväljundite omandamist.

Kvaliteetse õpetamise tagavad entusiastlikud ja oma valdkonda põhjalikult tundvad óppejõud, kes suhtlevad tudengitega positiivselt óppimist ja ópetamist soodustavas keskkonnas.

8. Olin motiveeritud saavutama kursusele seatud õpiväljundeid.

Motiveeritus tähendab soovi ja tahet pingutada mis tahes eesmärkide täitmiseks.

9. Valmistusin hoolikalt loenguteks ja seminarideks, et võtta nendest maksimum. Valmistusin õppetööks loengutes, seminarides või praktikumides põhjalikult. Otsisin lisalugemist, tegin õpitust vahekokkuvõtteid, töötasin läbi õppejõu pakutud informatsiooni ja allikad.

10. Mõtlesin, kuidas saaksin kursusel tõhusamalt õppida.

Võtsin aega, et mõelda, kuidas ma saan óppida efektiivsemalt.

11. Üldiselt olen selle kursusega rahul.

Kursus pakkus kvaliteetset õppimiskogemust.

12. Mis soodustas õpiväljundite omandamist?

13. Mis takistas õpiväljundite omandamist?

14. Soovitused ja arvamused kursuse parendamiseks. 


\title{
Learning in outcome based education - does it lead to student engagement?
}

\author{
Kaija Kumpas-Lenk ${ }^{a 1}$, Eve Eisenschmidt ${ }^{a}$, Kirsti Rumma ${ }^{a}$ \\ a School of Educational Sciences, Tallinn University
}

\begin{abstract}
Summary
Outcome based education (OBE) has been at the centre of European higher education reforms since the Bologna process in 1999 and has been implemented in Estonia since 2009. The knowledge, skills and attitudes expressed in the learning outcomes are key tools in supporting the implementation of student-centred learning. Although, the aim of the learning outcomes is to maximise support for students' individual development, it has emerged that OBE in Estonia is not fully practiced or implemented in the expected ways (Pilli \& Vanari, 2013; Tammets \& Pata, 2013; Udam et al., 2015). Moreover, learning outcomes are often seen as a bureaucratic burden that fulfils the aims of managerial and auditing processes, but not the actual needs of students (Hussey \& Smith, 2008). Most of the research within this topic is focusing on the challenges at the institutional levels, but there is little research that would reveal how students and teachers are experiencing the changes in the higher education area (Hadjianastasis, 2016) and whether these changes fulfil teachers aims in supporting students' personal development.

The research conducted in Estonian higher education show that there are problems, but also positive examples in implementing OBE. Pilli and Vanari (2013) acknowledged that the transition to the OBE has not been easy, but over the years, a positive trend in the alignment of learning outcomes, assessment tasks and learning assignments has emerged. Moreover, the external quality assessors' evaluations of the higher education institutions have pointed out that the challenge in today's Estonian higher education resides in transforming the teaching and learning paradigm into student-centered learning (Udam et al., 2015).

Although there are many positive steps taken towards student-centred OBE we have to acknowledge that the changes in learning and teaching paradigm take time (Rutiku et al., 2009). Recent studies show that active, self-regulated learning is not so common among Estonian students (Kumpas-Lenk, in review; Pilli et al., 2013; Roosalu et al., 2013; Vadi et al., 2014). Overall, students are
\end{abstract}

School of Educational Sciences, Tallinn University, Uus-Sadama 5, Tallinn 10120, Estonia; kkumpas@gmail.com 
satisfied with their learning experiences, the lack of major obstacles in achieving the intended learning outcomes (Kumpas-Lenk, in review), and their educational comfort zone (Vadi et al., 2014). Additionally, they do not feel the need for the implementation of student-centred learning or achieving personal learning goals (Roosalu et al., 2013), nor are they engaged or put any effort into their learning (Kumpas-Lenk et al., 2014). The results also show that students did not have enough opportunities to choose how to learn and to take responsibility of their learning. The research regarding Estonian students' learning illustrates how the changes have been put into practice and accepted.

The results of previous investigations based on the eVALUate student survey show that changes towards student-centred learning are not apparent in the latest surveys, because the agreement percentages of student engagement items are the lowest (Kumpas-Lenk et al., 2014). Research has shown that student engagement is the key between student-centred learning and achieving learning outcomes (Carini et al., 2006; Zepke et al., 2014) that are one of the universities quality assessment measures (Kahu, 2013). According to Kuh (2009), student engagement is mostly used when we talk about the quality of the students' time, the effort that they invest in reaching their goals, and the universities time and effort devoted in creating productive and engaging learning experiences (Kuh, 2001, 2009). Although, student engagement has been extensively studied, there is still confusion on how to clarify the construct of engagement. Kahu (2013) has systemised the research regarding student engagement approaches, which are: the behavioural perspective; the psychological perspective; the socio-cultural perspective and a holistic perspective. The proposed conceptual framework of student engagement acknowledges the importance of the student and the institution while recognising the critical influence of the socio-cultural context. In this study, we use Kahu's (2013) conceptual framework as the basis of characterising student engagement. In detail, we look at the aspects of the behavioural and psychological perspectives in the context of OBE.

In order to find out how OBE has been practiced, we need to understand how study processes have been planned and how students perceive these processes. Next to this, we cannot forget those who are at the centre of these processes - how motivated and ready are students for student-centred learning. The aim of this paper is to find out how students and teachers perceive the implementation of OBE by determining the factors, which aid the students' achievement of the intended learning outcomes. This study seeks answers to the following research questions:

1. According to students and teachers perceptions, how are the factors of learning process, student motivation, engagement and satisfaction supporting students in achieving the intended learning outcomes? 
2. What patterns emerge in students' and teachers' perceptions between student engagement and the components that support students' achievement of the intended learning outcomes?

This study was one part of a larger investigation, where a mixed type student evaluation survey, called eVALUate (Oliver et al., 2008), adapted in the Estonian context, was used to determine students' and teachers' experiences of students learning and achievement of the intended learning outcomes in their unit. The evaluation survey comprises 14 items, which ask students' perceptions on a categorical scale (strongly agree, agree, disagree, strongly disagree and unable to judge) regarding what supported their achievement of unit learning outcomes (Items 1-7), what they bring to their learning in terms of their motivation and engagement (Items 8-10), how satisfied they are with the studied unit (Item 11), what helped and hindered their learning with suggestions for improving the studied unit (Items 12-14) (Kumpas-Lenk et al., 2014). This study focuses on the quantitative section of the student evaluation survey (Items 1-11).

The participants were recruited from eight faculties (fields of economy, arts, health, social sciences) from six Estonian higher education institutions. A total of 1329 student surveys and 94 teaching surveys suitable for analysis were received (students' response rate $=36.2 \%$, teachers' response rate $=83.2 \%$ ).

To find out student and teacher perceptions about students' achievement of the intended learning outcomes, an aggregated percentage agreement (sum of the percentage of responses "Agree" and "Strongly agree"; "Achieved fully" and "Achieved mostly") was calculated and presented. In further analysis, "Uncertain" responses were eliminated and the analysis was carried out based on the 4-points Likert-type scale from "Strongly disagree" (1) ... "Strongly agree" (4). To determine statistically significant differences among teacher' and student' perceptions a non-parametric Mann-Whitney U-test was calculated by using SPSS Statistics Version 23.0. Average and means were calculated to illustrate the aspects where significant differences emerged. For explaining the results of student engagement items and aspects that support students' achievement of the learning outcomes a regression analysis was performed using the Backward method.

The results show that the components in the learning process (clear learning outcomes, experiences, resources, assessment, feedback, workload, teaching methods), student motivation and satisfaction support students in achieving the intended learning outcomes. However, student and teacher perceptions of the engagement items were much lower, which indicates that OBE is not fulfilling its aims in supporting student-centred learning where students take an active role and responsibility for their learning experiences. The analysis also showed that students and teachers experience students' learning in OBE 
similarly, most of the teacher and student responses were not statistically different, except the assessment tasks, motivation and satisfaction items.

In order to explain the low agreement of. student engagement items a regression analysis was conducted. The aim was to find out which components predict students' best use of the learning experiences (Item 9: I prepare for the lectures, seminars in order to take the maximum use out of these) and effective learning (Item 10: I thought about how to learn more effectively in this unit). The analysis of teacher responses showed that effective learning, workload and the learning environment predict the results of students' best use of the learning experiences and best use of the learning experiences, motivation and satisfaction predicted the results of effective learning. The analysis of student responses was similar and therefore effective learning, motivation and workload predicted the results of students' best use of the learning experiences. The results of the best use of the learning experiences, motivation and satisfaction items predicted the results of the effective learning.

It is evident that the change in teaching and learning paradigm with the help of OBE has not been fully put into practice. For engaging students, teachers and students should work as partners and focus on creating an environment that fully supports students' self-directed learning, use active and engaging learning methods and to take responsibility for their learning.

Keywords: outcome based education, student engagement, achievement of the intended learning outcomes in higher education, students and teachers' perceptions. 